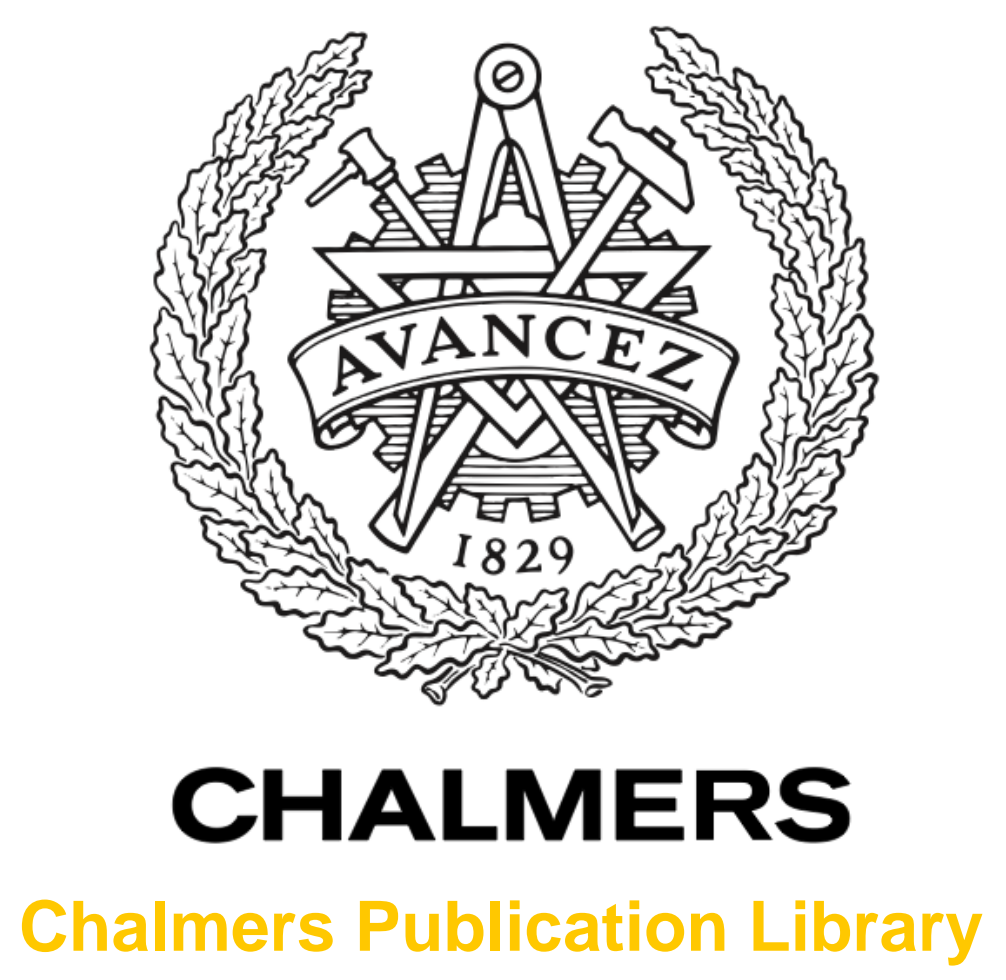

Bridging sanitation engineering and planning: theory and practice in Burkina Faso

This document has been downloaded from Chalmers Publication Library (CPL). It is the author's version of a work that was accepted for publication in:

Journal of Water Sanitation and Hygiene for Development (ISSN: 2043-9083)

Citation for the published paper:

McConville, J. ; Kain, J. ; Kvarnström, E. et al. (2011) "Bridging sanitation engineering and planning: theory and practice in Burkina Faso". Journal of Water Sanitation and Hygiene for Development, vol. 1(3), pp. 205-212.

http://dx.doi.org/10.2166/washdev.2011.042

Downloaded from: http://publications.lib.chalmers.se/publication/149442

Notice: Changes introduced as a result of publishing processes such as copy-editing and formatting may not be reflected in this document. For a definitive version of this work, please refer to the published source. Please note that access to the published version might require a subscription.

Chalmers Publication Library (CPL) offers the possibility of retrieving research publications produced at Chalmers University of Technology. It covers all types of publications: articles, dissertations, licentiate theses, masters theses, conference papers, reports etc. Since 2006 it is the official tool for Chalmers official publication statistics. To ensure that Chalmers research results are disseminated as widely as possible, an Open Access Policy has been adopted.

The CPL service is administrated and maintained by Chalmers Library. 


\title{
Bridging sanitation engineering and planning: Theory and practice in Burkina Faso
}

Jennifer McConville, Jaan-Henrik Kain, Elisabeth Kvarnström, Gunno Renman

Short title: Bridging sanitation engineering and planning

\section{Jennifer McConville (corresponding author)}

CIT Urban Water Management AB, Årstaängsvägen 1A, S-117 43 Stockholm, Sweden.

E-mail: jennifer.mcconville@ cit.chalmers.se

\section{Jaan-Henrik Kain}

Department of Architecture, Chalmers University of Technology, S-412 96 Göteborg, Sweden

\section{Elisabeth Kvarnström}

Vectura Consulting, Inc., Stockholm, Sweden

\section{Gunno Renman}

Department of Land and Water Resources Engineering, Royal Institute of Technology, SE 10044 Stockholm, Sweden

\begin{abstract}
The global challenge of providing sanitation services to the un-served underlines a need to change the way in which sanitation planning and service provision is approached. This paper offers a framework for categorizing sanitation projects planning processes based on planning steps and procedural planning theory to help engineers and sanitation planners gain a deeper understanding of the dynamics of these processes. The analysis identifies and discusses trends in both guidelines and actual sanitation programs. The results show that contemporary sanitation planning guidelines and field projects utilize patchwork processes of different planning modes, although the step of designing options is dominated by an expert-driven, rational-comprehensive approach. The use of planning theory can help engineers to ask critical questions about the objectives of the planning process and to develop contextappropriate planning processes that will make a difference for improving sanitation service provision.
\end{abstract}

Key words | planning theory, process, sanitation, service provision 


\section{INTRODUCTION}

The movement towards an integrated global economy requires engineers to play an increasingly larger role in critical international issues such as adaptation for climate change, poverty alleviation and promotion of sustainable development (Mihelcic et al. 2008). The challenge of meeting the world's needs for improved sanitation (e.g. disposing of human excreta) is one of these critical issues where engineers are needed to make significant positive impacts on environmental and public health, economy, and human dignity. However, sanitation has proved to be a difficult service to deliver in many situations. There is general agreement within the field of sanitation that the sector has failed to deliver substantial improvements to the most needy. For example, access to improved sanitation facilities in Burkina Faso was only $11 \%$ in 2008 (WHO \& UNICEF 2010). Despite the efforts made to reach the United Nations Millennium Development Goals, the world will meet only $43 \%$ of its target of halving the percentage of people without access to improved sanitation in 2015, leaving over 2.7 billion people under served (WHO \& UNICEF 2010).

The challenge of increasing sanitation services is that a strict engineering approach of estimating demand and designing a corresponding service delivery scheme often does not result in improved access. Globally, project evaluations repeatedly report cultural constraints, difficulties in securing behavioral change, prohibitive costs, lack of political and managerial support, or low community demand as reasons for low success rate of water and sanitation projects (World Bank 2003). The challenge in developing countries, which rely on on-site sanitation for a majority of urban and peri-urban dwellers, and with a large fraction of nonserved, thus goes beyond "normal" engineering skills and will have to address the issues listed above. Proper planning of sanitation interventions is therefore essential to identify and address such constraints. It is during the planning phase that critical decisions are made regarding choice of technology, budget, service area, demand creation and institutional management.

The large number of sanitation planning guidelines available underlines the growing consensus that process matters if sanitation improvements are to be made (e.g. UNICEF 1997; Kvarnström \& af Petersens 2004; WSSCC/Eawag 2005; IWA 2006). Many of these guidelines apply system-thinking and participatory methods under the belief that they will increase the potential for sustainability through better management of the numerous riskfactors and through improved local capacity for continued operation and maintenance (WSSCC/Eawag 2005). However, these tools for participation are often tacked on without clearly defining the ground-rules for the entire planning process, thus running the risk of 
missing much of the potential contribution from involving stakeholders. In order to improve sanitation programs, and the sanitation situation, it appears necessary to improve understanding of how the whole planning process is structured and why. The authors believe that a better understanding of planning theory can help engineers to more clearly define the focus of sanitation planning processes and the roles which various stakeholders should play, ultimately leading to more sanitation services being delivered to the non-served.

The objective of this paper is thus to (i) introduce concepts from the field of planning and (ii) use them to gain a better understanding of how sanitation planning is currently being designed and practiced.

\section{METHODS AND MATERIALS}

This paper builds an analytical framework that attempts to capture two dimensions of the planning process; when actions are taken in the process (planning steps), and how they are performed (procedural planning theory). The time dimension is captured using five generic planning steps that were identified in previous studies (Kvarnström \& McConville 2007; McConville 2010). The five main steps in a planning framework are: (1) Problem identification, (2) Defining objectives, (3) Design options, (4) Select solutions, and (5) Action plan for implementation. The analysis uses the generic steps as a backbone structure, so that how planning is done can be assessed within each step in the process.

In order to examine differences in planning styles this paper draws on existing theories of procedural planning. There is a wide variety of literature on procedural planning that go into minute intricacies, yet for the purposes of this investigation it has been useful to develop a simplified typology of procedural planning modes in order to make the discussion more accessible. Out of the proliferation of existing planning approaches, five major strands of theory have thus been chosen for the typology (Table 1): rational-comprehensive (Faludi 1973), incremental (Lindblom 1959), advocacy (Davidoff 1965), collaborative (Healey 1997), and post-modern (Allmendinger 2001). Inspired by Hudson (1979), the ambition is that these five strands, together, cover the larger part of the wide spectrum of planning approaches. It should be noted that some of them are more like ideal types of planning (e.g. rationalcomprehensive) while others are based on empirical studies of what planners actually do (e.g. incremental). Also, they are not at all mutually exclusive, but can be combined in different ways to better support planning, see e.g. Critical Pragmatism (Forester 1999). Yet, for the 
purpose of this article, they are seen to represent five distinctive understandings of what planning is all about.

Case study methodology was selected as the primary research methodology for understanding how sanitation planning is currently being designed and practiced. Case studies focus on the in-depth study of single cases as a way to learn from practical experience in a complex situation with too many uncontrolled variables. Results can be generalized as long as it is kept in mind that the results are an analytical generalization and not a statistical generalization (Yin 2003). The framework was applied to the study of two sanitation planning guidelines (i.e. theoretical models) and two implemented projects from the field (i.e. local practice in Burkina Faso). Data gathering was carried out through literature reviews for the guidelines and document reviews, interviews and site visits for the projects. Case study methodology (Yin 2003) was applied during data collection and analysis to assure accuracy of the information.

The two selected planning guidelines are widely known in the sanitation field and are supported by creditable institutions. They were chosen because they can be considered representative of engineers' perspectives in sanitation, i.e. those of: (1) engineering consultants as in Open Wastewater Planning (OWP) (Kvarnström \& af Petersens 2004; Bodik \& Ridderstolpe 2007) and (2) sanitation researchers/experts involved in international development, example of Household-Centered Environmental Sanitation (HCES) (WSSCC/Eawag 2005).

The focus of this study was Burkina Faso (population 14.7 million), a land-locked Francophone country in the semi-arid savanna of West Africa. It is a semi-presidential republic, although there is a progressive movement towards decentralization, and most infrastructure decision-making remains within national institutions. Burkina Faso ranks 178 out of 182 countries on the Human Development Index (UNDP 2009a), with GDPs per capita of US\$1083.

The field projects were chosen because they represent both the non-governmental organization (NGO) and national government perspective on sanitation delivery, which are the primary means of sanitation service delivery in Burkina Faso. Although these case studies give a wider picture of how different actors practice sanitation planning in the local context, the small number of cases does make for some limitations regarding the ability to draw conclusive generalizations. It should thus be kept in mind throughout the analysis that this paper offers an entry point for discussion and that many more cases at all scales would be necessary to draw definite arguments regarding local practices. The first is a project supported 
by CREPA (Centre Régional pour l'Eau Potable et l'Assainissement à faible coût), an interstate institution and the leading applied-research institute for appropriate and affordable sanitation in French-speaking West Africa. The second is the highly regarded Strategic Sanitation Plan for the city of Ouagadougou (PSAO) in Burkina Faso.

\section{RESULTS AND ANALYSIS}

Analysis of the guidelines and projects involves dividing the respective planning processes into the five generic planning steps and then categorizing each step based on which planning mode appears to be dominant. The results presented below give a brief description and analysis of the guidelines and field projects, as well as explain the classifications presented in Table 2.

\section{Open wastewater planning}

The OWP guidelines seek to include a wider range of selection criteria and possible options by encouraging a participatory approach that is lead by an independent expert who has a good knowledge of both sanitation solutions and of the local policy context (Bodik \& Ridderstolpe 2007).

The first step emphasizes sharing individual viewpoints and building a basis for civic action, making this step a post-modern planning mode. The second step moves from sharing viewpoints to reaching consensus on criteria for designing appropriate systems, thus using a collaborative approach to planning. The third step has limited participation and high degree of expert control in the design process, making this a rational-comprehensive approach. When the expert has prepared a choice of options, these are presented to the community for selection of the most appropriate solution. Although there are some rational-comprehensive (expert) elements in the selection process, the level of participation and pragmatic decision-making is more typical of incremental planning. Unlike the other processes used in this analysis, the Open Planning approach does not go into detail on how a selected system should be implemented, therefore planning for action is not part of this approach.

\section{Household-centered environmental sanitation}

The HCES approach is a multi-sector approach for service delivery in poor urban areas. It integrates water supply, storm-water and sewage management; facilitates the incorporation of input from diverse actors; and utilizes the concept of urban zones for enhancing the 
implementation of decentralized options (WSSCC/Eawag 2005). The HCES guidelines have been subsequently field tested and revised, including reducing the number of planning steps from 10 to 7. The new, renamed 'Community-led Urban Environmental Sanitation (CLUES)' guidelines will be published in 2011 by SANDEC and WSSCC.

The identification of problems and objectives in the HCES approach are focused on ensuring community participation and giving a voice to the people who will benefit from the services, which classifies these first two steps as advocacy. Similar to Open Planning, the design and selection processes are led by experts who identify service combinations that meet the levels of service desired by the users. Once possible service plans are identified, the planners assist the community in reaching agreement on which option makes the most sense to implement. Again, the expert-led design of options followed by the facilitated community selection process makes these two steps first rational-comprehensive and then incremental. The action plan is developed through an open dialogue with stakeholders regarding the best way to achieve implementation, a style which is most in line with collaborative planning.

\section{CREPA program for basic community services, Burkina Faso}

CREPA runs a program to support the development of basic community services, including sanitation. This study examines a project initiated in the small town of Tougan (population ca 16,000) in northwest Burkina Faso (CREPA 2006). The project started after a request for assistance from the Mayor who wanted to prioritize sanitation in the town.

Similar to the process recommended by HCES, CREPA conducted the processes of problem identification and defining objectives in a participative way using an advocacy approach to give a voice to community members. A day of public dialogue was held where community members were asked to discuss town problems, possible solutions and/or objectives for action. However, the designing step that followed the collection of community viewpoints and priorities used a more expert-driven approach. Based on the baseline studies and community defined objectives, CREPA experts prepared a project document, including the design and selection of appropriate technologies for community-identified problems. The focus of the project document is aimed at offering a comprehensive package of sanitation services with technology choice based on the analyses performed by experts, which gives both the design and selection steps a rational-comprehensive feel.

It is somewhat harder to classify what planning mode is used in the action plan implemented by CREPA, since there is a mix of rational-comprehensive, post-modern and 
incremental elements. The main efforts of project implementation were focused on the social marketing campaign, which was to create demand for sanitation (i.e. selling the expertdefined rational-comprehensive plan) through awareness-raising techniques and then offer the households a choice of sanitation technologies (post-modern individual choice). In addition, a CREPA intern had daily contact and communication with the field workers and users, and worked to verify results and remedy problems as they arose (i.e. incremental problemsolving). Despite the elements of expert rationality and post-modern individual choice, the dominant focus of the action plan was still getting things built. It is thus mainly based on a pragmatic, incremental planning mode that focuses on trial-and-error learning and patch-work implementation in the households most willing to buy into the project.

\section{Strategic sanitation plan of Ouagadougou, Burkina Faso}

The initiative for a sanitation plan in the capital of Burkina Faso started in the early 1990s through collaboration between the National Office of Water and Sanitation (ONEA) and the regional UNDP-World Bank Water and Sanitation Program (WSP). The Strategic Plan for Sanitation in the city of Ouagadougou (PSAO) rests on two innovative concepts: financing of sanitation infrastructure through surtax on water provision and recognition that conventional sewerage is not an affordable option for the entire city. The planning process used for the PSAO has subsequently been recommended for other urban areas in Burkina Faso (ONEA 2007).

The PSAO started as an action-oriented program under the leadership of high-level officials and expert staff at ONEA. The principles outlined in the PSAO project document are related to short-term planning with an emphasis on immediate actions (WSP 1994). Although this get-it-done focus is typical of an incremental approach to planning, both problem identification and setting of objectives were highly expert-driven and far-reaching. Project documents contain expert studies on urban habitat and geology, capacity and willingness-topay of the local population, and institutional studies for financial mechanisms and partners for executing the program. The resulting problem description and program objectives outlined in the planning document give a comprehensive view of the problem and specific objectives for improving sanitation services. Consequently, these first two steps are classified as rationalcomprehensive.

As far as could be understood from interviews conducted and documentation available, the designing and selection steps were carried out within the ONEA planning team, but with 
some feedback from the main stakeholders involved in the initial dialogue. Similar to the CREPA case, the diversity of options in the project document appears aimed at offering a comprehensive package of sanitation service options. The design and selection of which technologies to offer remained under the control of experts, with limited wider stakeholder participation, indicating that a rational-comprehensive mode of planning also dominated these steps of the process.

The action planning step, however, focuses more on an incremental approach as a means of getting things done. The execution strategy was planned to be implemented and refined in a step-wise process, starting with a pilot phase from 1992 to 1993 , where the selected sanitation options were demonstrated in two neighborhoods. In addition to assessing technical feasibility, the pilot project was a means to clarify the roles and responsibilities of different institutions involved in the process. After the results of the pilot projects were found to be positive, the strategy was scaled-up and formalized as sanitation policy for the entire city.

\section{DISCUSSION}

The analysis of the selected guidelines and field projects highlights several interesting similarities and differences in how they outline sanitation planning processes. By using a planning theory typology it becomes clear that the two studied planning guidelines tend to propose communicative approaches to sanitation planning (e.g. post-modern or collaborative) whereas the field projects are significantly more inclined towards working in a rationalcomprehensive way.

One reason for this divide may be that it is too early yet to see evidence of an ongoing shift in planning practices globally, from rational-comprehensive approaches towards collaborative ones. Tewdwr-Jones \& Allmendinger (1998) argue that changes towards a practical application of collaborative or post-modern modes of planning are often made at the individual level by planners eager to try a new approach, but that their actions are undertaken within an institutional structure that is still "top-down". A more significant shift to collaborative planning will thus require a redesign of institutions so as to overcome existing power structures (Tewdwr-Jones \& Allmendinger 1998). For example, interviews with sanitation planners and practitioners in Burkina Faso make it clear that ideals of participation and communicative theory have infiltrated significantly into their perspectives and rhetoric (McConville et al. 2010). Perhaps it is simply a matter of time before the activities in local projects will begin to more fully reflect the theories espoused in the planning guidelines. At 
the same time it is critical to recognize that power structures and institutional bureaucracy do exist and may limit the potential to successfully apply collaborative approaches to sanitation planning (Kvarnström et al. 2006).

On a more detailed level of analysis there are differences to be found in the focus and approaches taken by the sanitation development researchers (HCES), on the one hand, and the sanitation engineering consultants (OWP), on the other. For example, HCES favors the advocacy planning mode for their work in developing countries, while OWP focuses on creating dialogue through collaborative and post-modern modes. Similarly, there are differences between the field projects, so that one can suspect that differences in planning styles may be traced back to conflicting perspectives on development programs between different lead agencies, such as a national sanitation agency and an inter-state organization.

According to this analysis, the process of designing options (e.g. type of toilet) in the field of sanitation remains expert-led and uses a rational-comprehensive mode of planning in all of the studied guidelines and field projects. Essentially, all four of the guidelines and field projects studied involve the experts coming up with a handful of possible designs that are then offered to the stakeholders (either in the selection or implementation step). Some would argue the need for expert guidance to manage the complexity of sanitation systems and to assure proper containment and treatment of excreta (WHO 2006). However, rational-comprehensive approaches have been criticized for resulting in plans that are all too simplified versions of reality and therefore impossible to implement in real world contexts (Allmendinger 2009). In a situation where drastic change is needed to meet the needs of the un-served, it can also be argued that such technocratic approaches end up lacking critical connections with the socioeconomic reality of the situation (Tiberghien et al. 2011). An example from the PSAO case is how households theoretically could choose any on-site system they desired, but where households, nonetheless, most frequently chose the least expensive options saying it was all they could afford (McConville personal observation 2007).

This study thus highlights a tension within the sanitation sector between rhetoric for community-based and participatory approaches and the need to meet strict treatment standards. On one hand it could be argued that more communicative and participatory approaches in the design step would have increased the range of feasible choices, thus opening up for more adaptive and sustainable sanitation provision (WSSCC/Eawag 2005). On the other hand, it may be argued that the need to meet treatment standards implies that this step should remain dominated by the tried-and-tested technologies that experts can vouch for, regardless of the potentially weak compatibility of these technologies with the local cultural 
and socioeconomic context. Even if it is not yet clear how to achieve a balance between potentially conflicting needs, this study points to the design options and select solution steps as key entry points for significantly changing how sanitation planning is perceived and practiced.

Another key point is that none of the studied guidelines and field projects used a single planning approach throughout the whole planning process. One interpretation may be that this is a result of a haphazard use of different planning styles rather than a deliberate shaping of the planning process. However, another explanation could be that the guidelines and projects do adapt to the diverse needs of the different planning steps, even if this is not discernible in the discourses present in the actual guidelines and field projects (McConville 2010; field observations). This would seem to indicate a weak knowledge of planning theory in the sector of sanitation provision, and hence a critical opportunity for learning and improving the understanding of the planning process itself. Previous studies suggest that a combination of different planning methods might be needed to better adapt to local context (Lüthi et al. 2009). However, it should be noted that this cannot be a matter of coincidental ad hoc mixing of different planning modes but rather needs to be about an intentional mixing with the aim to maximize effectiveness of the process. Increasing knowledge regarding available planning approaches thus offers an opportunity to constructively deal with the complex challenges of the local situation.

\section{CONCLUSIONS}

One of the key starting points for this study was the question whether bridging the disciplines of planning and engineering could contribute to a better understanding of the practice of sanitation provision. As an analytical framework, the use of planning theory has been a useful tool for identifying differences and trends in both sanitation planning guidelines and sanitation practice. In addition, planning theory could also prove valuable for sanitation planners to become more consciously aware of the pros and cons of different planning modes and to deliberately apply them in the design of their planning processes, for improved effectiveness of processes for sanitation provision, as well as for better sustainability of the system once it is in place. There is no right or wrong answer to these questions; rather it is about choosing the right approach for the specific context. Here, the use of planning theory can help engineers ask critical questions about the objectives of the planning process, about the best way to reach these objectives and, not least, about their own role within it. By understanding the potential variation in planning styles along a planning process, linking it to 
engineering design, and acknowledging that this process is not necessarily uniform; the practitioner can start to identify areas of weakness and better adjust the process to match local needs. This could mean exploring ways to make the designing step of the process less expertdriven or recognizing opportunities early in a process for integrating a wider variety of stakeholders' criteria. In conclusion, by focusing on procedural aspects of planning, this paper contributes to an improved understanding of the importance of the structure and objectives of the sanitation planning process itself.

\section{REFERENCES}

Allmendinger, P. 2001 Planning in Postmodern Times. Routledge, London.

Allmendinger, P. 2009 Planning Theory, 2nd ed. Palgrave Macmillan, New York.

Bodik, I. \& Ridderstolpe, P. 2007 Sustainable Sanitation in Central and Eastern Europeaddressing the needs of small and medium-size settlements. Global Water Partnership Central and Eastern Europe: Slovakia.

CREPA. 2006 Rapport de synthèse des entretiens avec les personnes ressources, les services techniques et les $O B C$ de la ville Tougan. CREPA report, Ouagadougou, Burkina Faso.

Davidoff, P. 1965 Advocacy and Pluralism in Planning. J. Am. Inst. Plann. 31, 544-555.

Faludi, A. 1973 Planning Theory. Pergamon, Oxford.

Forester, J. 1999 The Deliberative Practitioner: Encouraging Participatory Planning Processes. The MIT Press, Cambridge, Massachusetts.

Healey, P. 1997 Collaborative Planning: Shaping Places in Fragmented Societies. Macmillan Press Ltd., Hong Kong.

Hudson, B. 1979 Comparison of Current Planning Theories: Counterparts and Contradictions. J. Am. Plann. Assoc. 45, 387-398.

International Water Association (IWA). 2006. Sanitation 21: Simple Approaches to Complex Sanitation, a Draft Framework for Analysis. London: International Water Association. Kvarnström, E. \& af Petersens, Ebba. 2004. Open Planning of Sanitation Systems, Report 2004-3. EcoSanRes Program, Stockholm Environment Institute: Stockholm, Sweden.

Kvarnström, E., Emilsson, K., Richert-Stintzing, A., Johansson, M., Jönsson, H., af Petersens, E., Schönning, C., Christensen, J., Hellström, D., Qvarnström, L., Ridderstolpe, P. \& Drangert, J-O. 2006. Urine Diversion: One Step Towards Sustainable Sanitation. Stockholm Environment Institute, EcoSanRes Publication Series, report 2006-1. 
Kvarnström, E. \& McConville, J. 2007 Sanitation Planning - A Tool to Achieve Sustainable Sanitation? In: Huber, H., Wilderer P. \& Paris, S. (eds). Proceedings of Water Supply and Sanitation for All, conference held in Berching, Germany, Sept 26-28, 2007.

Lindblom, C.E. 1959 The Science of "Muddling Through". Public Adm. Rev. 19, 79-88.

Lüthi, C., McConville, J. \& Kvarnström, E. 2009 Community-based approaches for addressing the urban sanitation challenge. Int. J. Urban Sustain. Dev. 1, 49-63.

McConville, J.R. 2010 Unpacking Sanitation Planning: Comparing Theory and Practice. Doctoral Thesis in Architecture. Chalmers University of Technology, Gothenburg, Sweden.

McConville, J., Kain, J.H. \& Kvarnström, E. 2010 Perceptions of Local Sustainability in Planning Sanitation Projects in West Africa. In Vliet, B., Spaargaren, G. and Oosterveer, P (eds). Social Perspectives on the Sanitation Challenge. Springer, Dordrecht, The Netherlands.

Mihelcic, J.R., Paterson, K.G., Phillips, L.D., Zhang, Q., Watkins, D.W., Barkdoll, B.D., Fuchs, V.J. \& Fry, L.M. 2008 Educating engineers in the sustainable futures model with a global perspective. Civil Eng. Environ. Syst. 25, 255-263.

ONEA. 2007 Note d'orientation pour l'élaboration de plans stratégiques d'assainissement des eaux usées et excréta dans les centres urbains et semi-urbains du Burkina Faso. Système de management de la qualité (norme ISO 9001 / 2000) - Document de référence - Processus : Promouvoir l'Assainissement. ONEA, Burkina Faso.

Tewdwr-Jones, M. \& Allmendinger, P. 1998 Deconstructing communicative rationality: a critique of Habermasian collaborative planning. Environ. Plann. A, 30, 1975-1989.

Tiberghien, J.E., Robbines, P.T. and Tyrrel, S.F. 2011 Reflexive assessment of practical and holistic sanitation development tools using the rural and peri-urban case of Mexico. $J$. Environ. Manage. 92, 457-471.

UNICEF. 1997 Towards Better Programming: A Sanitation Handbook. Watre, Environment and Sanitation Technical Guidelines Series - No. 3 EHP Applied Study No. 5, UNICEF, New York, NY, USA.

World Health Organization (WHO). 2006 Guidelines for the Safe Use of Wastewater, Excreta and Greywater, Volume 4: Excreta and greywater use in agriculture. WHO, Geneva, Switzerland.

WHO \& UNICEF (Joint Monitoring Program by World Health Organization and United Nations Children's Emergency Fund). 2010 Progress on Sanitation and Drinking Water, 2010 Update. WHO, Geneva, Switzerland and UNICEF, New York, USA. 
Water and Sanitation Program-Africa Region (WSP). 1994 Projet d'Amélioration des Conditions de Vie Urbaine - Assainissement Urbain à Ouagadougou - Diagnostic Propositions. Ministère des Travaux Publies de l'Habitat et de l'Urbanisme, Direction du 3eme Projet de Développement Urbain, Burkina Faso.

World Bank. 2003 Efficient, Sustainable Service for All? An OED Review of the World Bank's Assistance to Water Supply and Sanitation. Operations Evaluation Department, The World Bank, Report No. 26443.

WSSCC/Eawag. 2005 Household-Centred Environmental Sanitation: Implementing the Bellagio Principles in Urban Environmental Sanitation, Provisional Guideline for Decision-Makers. Eawag, Duebendorf, Switzerland.

Yin, R.K. 2003 Case Study Research: Design and Methods - Third edition. Sage Publications Inc., Thousand Oaks, CA, USA. 
Table 1 Comparison of trends and focus in the five planning theories presented (Adapted from Allmendinger 2009).

\begin{tabular}{|c|c|c|c|c|c|}
\hline & $\begin{array}{c}\text { Planning } \\
\text { Focus }\end{array}$ & $\begin{array}{c}\text { Role of } \\
\text { Planner }\end{array}$ & $\begin{array}{c}\text { Planning } \\
\text { Method }\end{array}$ & Participation & Outcome \\
\hline $\begin{array}{l}\text { Rational- } \\
\text { Comprehensive }\end{array}$ & $\begin{array}{l}\text { Achieving far- } \\
\text { reaching } \\
\text { global } \\
\text { objectives }\end{array}$ & $\begin{array}{l}\text { Objective } \\
\text { expert }\end{array}$ & $\begin{array}{l}\text { Based on } \\
\text { quantitative } \\
\text { analysis }\end{array}$ & Limited & Master Plan \\
\hline Incremental & $\begin{array}{l}\text { Getting things } \\
\text { done - no set } \\
\text { objectives }\end{array}$ & $\begin{array}{l}\text { Facilitator: } \\
\text { helping others } \\
\text { act of ideas } \\
\text { that make } \\
\text { sense }\end{array}$ & $\begin{array}{l}\text { Agreement after } \\
\text { weighting } \\
\text { specific options } \\
\text { and outcomes }\end{array}$ & $\begin{array}{l}\text { Generally by } \\
\text { strong or well } \\
\text { articulated } \\
\text { players }\end{array}$ & $\begin{array}{l}\text { Compromise } \\
\text { patch-work } \\
\text { plans }\end{array}$ \\
\hline Advocacy & $\begin{array}{l}\text { Solutions to } \\
\text { address power } \\
\text { inequalities }\end{array}$ & $\begin{array}{l}\text { Advocate: } \\
\text { giving a voice } \\
\text { to interest } \\
\text { groups }\end{array}$ & $\begin{array}{l}\text { Debate and } \\
\text { discussion }\end{array}$ & $\begin{array}{l}\text { Through } \\
\text { representatives }\end{array}$ & $\begin{array}{l}\text { Political } \\
\text { debate }\end{array}$ \\
\hline Collaborative & $\begin{array}{l}\text { Agreement } \\
\text { through free } \\
\text { and open } \\
\text { discussion }\end{array}$ & $\begin{array}{l}\text { Moderator: } \\
\text { enabling } \\
\text { communication } \\
\text { between } \\
\text { stakeholders }\end{array}$ & $\begin{array}{l}\text { Open dialogue } \\
\text { leading to } \\
\text { consensus }\end{array}$ & $\begin{array}{l}\text { Decentralized: } \\
\text { invitation to } \\
\text { everyone who } \\
\text { wishes to } \\
\text { communicate }\end{array}$ & $\begin{array}{l}\text { Consensus for } \\
\text { action }\end{array}$ \\
\hline Post-modern & $\begin{array}{l}\text { Understanding } \\
\text { and sharing } \\
\text { fragmented } \\
\text { visions - no } \\
\text { great vision }\end{array}$ & $\begin{array}{l}\text { Narrator: } \\
\text { allowing } \\
\text { individuals to } \\
\text { express their } \\
\text { viewpoints }\end{array}$ & $\begin{array}{l}\text { Iterative and } \\
\text { participatory, } \\
\text { but } \\
\text { individualized }\end{array}$ & $\begin{array}{l}\text { Network for } \\
\text { those who can } \\
\text { engage in } \\
\text { planning }\end{array}$ & $\begin{array}{l}\text { Civic culture, } \\
\text { but individual } \\
\text { action }\end{array}$ \\
\hline
\end{tabular}

Table 2 Overview of how planning is carried out during each step of the planning guidelines and the field projects.

\begin{tabular}{|c|c|c|c|c|}
\hline & \multicolumn{2}{|c|}{ Planning Frameworks } & \multicolumn{2}{|c|}{ Field Projects } \\
\hline & OWP & HCES & CREPA & PSAO \\
\hline $\begin{array}{c}\text { Problem } \\
\text { identification }\end{array}$ & Post-Modern & Advocacy & Advocacy & $\begin{array}{c}\text { Rational- } \\
\text { Comprehensive }\end{array}$ \\
\hline Define objectives & Collaborative & Advocacy & Advocacy & $\begin{array}{c}\text { Rational- } \\
\text { Comprehensive }\end{array}$ \\
\hline Design options & $\begin{array}{c}\text { Rational- } \\
\text { Comprehensive }\end{array}$ & $\begin{array}{c}\text { Rational- } \\
\text { Comprehensive }\end{array}$ & $\begin{array}{c}\text { Rational- } \\
\text { Comprehensive }\end{array}$ & $\begin{array}{c}\text { Rational- } \\
\text { Comprehensive }\end{array}$ \\
\hline Select solutions & Incremental & Incremental & $\begin{array}{c}\text { Rational- } \\
\text { Comprehensive }\end{array}$ & $\begin{array}{c}\text { Rational- } \\
\text { Comprehensive }\end{array}$ \\
\hline $\begin{array}{l}\text { Action plan for } \\
\text { implementation }\end{array}$ & & Collaborative & Incremental & Incremental \\
\hline
\end{tabular}

